"In press": Arctic, Antarctic and Alpine Research, June 2005

\title{
Changes in Subantarctic Heard Island Vegetation at Sites Occupied by Poa annua, 1987-2000
}

\author{
J.J. Scott and J.B. Kirkpatrick \\ School of Geography and Environmental Studies, University of Tasmania, Private Bag 78, \\ GPO, Hobart, Tasmania 7001, Australia
}

\begin{abstract}
Poa annua, the only alien plant species recorded on subantarctic Heard Island, considerably expanded its range and abundance along three transects in tundra-like vegetation on the island in the period 1987-2000. This expansion was strongly associated with increased seal disturbance, which also favoured Callitriche antarctica and damaged Pringlea antiscorbutica, leading to a decrease in mean vegetation height. Expansions of Azorella selago and Poa cookii were independent of the expansion of $P$. annua, relating to colonization of moraines. There was no evidence of displacement of other taxa by Poa annua in areas undisturbed by seals.
\end{abstract}

\section{Introduction}

Heard Island lies south of the Antarctic Polar Frontal Zone in the southern Indian Ocean $\left(53^{\circ}\right.$ $5^{\prime} \mathrm{S}, 73^{\circ} 30^{\prime} \mathrm{E}$; Fig. 1). Only a small proportion of its $367-\mathrm{km}^{2}$ area is ice free and available for vegetation colonization, although these proportions are increasing due to rapid glacial retreat over the past few decades (Kieman and McConnell, 1999; Ruddell, in press).

However, at low altitudes there are patches of species-poor tundra-like vegetation which cover more than $20 \mathrm{~km}^{2}$ of the land area (Scott and Bergstrom, in press). The vegetation of Heard Island is unusual in the subantarctic region as there appear to be no human-introduced alien plant species (Scott, 1989). Here, 'alien' is defined as 'introduced to an ecosystem as a result of human activity (including species that arrive by natural means to a specific ecosystem but are alien to that biogeographical zone)' (Frenot et al., 2005). The one alien species, Poa annua, was first recorded in 1987 from two sites on eastern Heard Island, both on moraine outwash deposits near the edges of retreating glaciers which covered the sites in 1947 (Scott, 1990) (Fig. 1). Neither site was directly linked with human presence on the island (Scott, 1989). It appears most likely that seabirds transported seeds of $P$. annua to Heard Island (Scott, 1989), possibly from the closest landmass, lles Kerguelen, where it is widespread (Frenot et al., 2001). The species typically takes on a perennial habit in the subantarctic (Frenot and Gloaguen, 1994; Gremmen, 1997), although is usually an annual in temperate locations.

In 1987 one of us (Scott) collected vegetation and environmental data from 61 quadrats along four transects in the two locations where $P$. annua occurred. In November 2000 , after a period of 13 years, the two $P$. annua populations on Heard Island were re-visited. Scott was able to relocate 37 of the quadrats along three of the transects. Vegetation and environmental parameters were remeasured, the distribution of $P$. annua at the two sites was remapped, and changes in distribution and patterns of colonization were documented. In this paper we report the changes that have taken place in the vegetation of the quadrats; relate $P$. annua expansion to environment, seal disturbance and floristic variation; and test whether there is any indication that $P$. annua might displace native species. 


\section{Methods}

The $375 \times 2 \mathrm{~m}$ quadrats were located along two transects at the Winston Lagoon site and one at the Stephenson Lagoon site (Figs. 1 and 2) which were originally placed to pass through the main populations of $P$. annua. The extent of $P$. annua in these areas was mapped at both times using colour aerial photographs and ground observation, in 1987 using pacing and compass bearings, and in 2000 using a GPS unit with an expected accuracy of $10-30 \mathrm{~m}$.

The cover of each vascular plant species, genera or species of bryophytes, filamentous green algae as a class, bare ground, rock cover and free-standing water was recorded for each quadrat using the following classes: $1,<1 \% ; 2,1-5 \% ; 3,5-25 \% ; 4,25-50 \% ; 5,50-75 \% ; 6$, $75-100 \%$. Two moss genera, Bryum and Pohlia, were combined during analyses due to insufficient sampling in 2000 to allow accurate identifications. The resulting category "Bryum spp./Pohlia spp." is characteristic of moist habitats such as springs and seepage lines, and is likely to include Bryum pseudotriquetrum and Pohlia wahlenbergii. The influence of seal disturbance was visually estimated in four classes ( 0 , none; 1 , slight; 2 , moderate; 3 , heavy) by taking into account relative disturbance from vegetation trampling and manuring, deposition of hair and skin, and creation of bare ground (Scott 1990). The maximum height of the vegetation was measured to the nearest centimeter. Altitude was determined with an altimeter, slope with a clinometer, and aspect with a compass. Soil depth in centimeters was estimated as the maximum penetration of three probes. These latter four variables were measured only in 1987, while the others were measured or estimated in both 1987 and 2000 .

Four communities were chosen from a manually-sorted table of the quadrat data. Global nonmetric multidimensional scaling (mds) was used to ordinate the floristic data set, using the default options in DECODA (Minchin, 1990). Scores for each quadrat in 1987 were subtracted from the scores for each quadrat in 2000 to give change indices for all variables. Pearsons product moment correlation coefficient, one way ANOVA, the paired $t$-test, and chi-squared were used to determine the significance of relationships between variables, or the significance of differences between sets of values, as appropriate.

\section{Results}

Four intergrading communities were selected from the sorted table. All had quadrats from both sample times (Table 1). Three ordination axes were selected, as the stress declined only a little between axes 3 and 4 . The four communities occupy statistically distinct sections of ordination space (Table 2). In general, our communities fit into the broad exploratory classes of Scott and Bergstrom (in press).

In Community 1, Poa annua had its highest mean abundance out of all the communities and was the only species with its peak abundance in this community. Poa kerguelensis and Pringlea antiscorbutica had their lowest mean abundance. Community 1 falls within the "coastal biotic vegetation" complex and was located at low altitudes with gentle slopes, low rock cover, high water cover, and a moderate to high level of seal disturbance. Mean vegetation height and species richness were both relatively low (Table 2), and most quadrats were located on the Winston transects. In Community 2, Callitriche antarctica, Deschampsia antarctica, Montia fontana, Poa cookii, and Ceratodon purpureus had their highest mean abundance, and mean vegetation height and species richness were the highest for the four communities. Community 2 is included in the "wet mixed herbfield" complex and occupied low altitudes with moderate slopes, low rock cover, high water cover, and a 
moderate to low level of seal disturbance (Table 2). All quadrats were from the Winston transects.

In Community 3, Azorella selago, Pringlea antiscorbutica and Ceratodon purpureus had their highest mean abundance values. Community 3 fits between the "wet mixed herbfield" complex and "open cushionfield" vegetation categories, and occupied drier locations than the previous two communities, at low altitudes with moderate slopes and low rock cover, and a moderate to low level of seal disturbance. Mean vegetation height and species richness were both relatively high (Table 2), and nearly all quadrats were from the Winston transects. In Community 4, Colobanthus kerguelensis and Poa kerguelensis had their highest mean abundance and Azorella selago its second highest mean abundance, while $P$. annua, Callitriche antarctica, Deschampsia antarctica, Montia fontana, P. cookii, and Ceratodon purpureus had their lowest. Community 4 corresponds to "open cushionfield/unstable fellfield" vegetation, and occupied higher altitudes with gentle slopes, high rock cover, low water cover and moderate to low seal disturbance levels. It had relatively low mean vegetation height and species richness, and nearly all quadrats were located on the Stephenson transect.

Most quadrats that were in Communities 2 and 4 in 1987 remained in these communities in 2000 (Table 1). Of the 12 quadrats in Community 3 in 1987 , only six remained in this community in 2000, the remainder moving to Community 1 (four quadrats) and Community 2 (two quadrats). The five quadrats that were in Community 1 in 1987 remained there in 2000 (Table 1), and the community gained another seven quadrats from Communities 2, 3 and 4 - mainly from Community 3 . Thus, the major transition in the time period was from Community 3 to Community 1 , and the major changes occurred on the Winston transects rather than the Stephenson transect. As indicated in Table 2, the transition was to a less species-rich community characterized by lower vegetation height; a higher abundance of $P$. annua, Callitriche antarctica and P. cookii; and a lower abundance of Azorella selago, Colobanthus kerguelensis, Deschampsia antarctica, Montia fontana, P. kerguelensis, Pringlea antiscorbutica, and Ceratodon purpureus. In environmental terms, the transition was to a situation where elephant seal disturbance was greater and there was more freestanding water. The increase in free-standing water is a likely consequence of seal trampling and wallowing, although seasonal snow melt may have also played a role, as the 2000 measurement was done in November with remnant winter snow-cover and the 1987 measurement in December, when all snow had melted.

P. anmua, Callitriche antarctica, Azorella selago, P. cookii, and filamentous green algae significantly increased in abundance between 1987 and 2000 (Table 3). Pringlea antiscorbutica, Deschampsia antarctica, and Ceratodon purpureus significantly decreased in abundance over the same time period (Table 3). Despite considerable and consistent compositional change, as shown in significant reductions in mds (ordination) axis one and three scores (Table 3), mean species richness did not change (Table 3). Vegetation height declined significantly (Table 3), a phenomenon largely associated with the destruction of Pringlea antiscorbutica by a significant increase in seal disturbance (Table 3). Bare ground significantly decreased $(\mathrm{P}<0.01)$, while water cover significantly increased $(\mathrm{P}<0.05)$ and rock cover remained relatively constant (Table 3 ).

In 28 of the 37 quadrats, $P$. annua cover increased between 1987 and 2000 . Its cover decreased in three quadrats and remained the same in six. The three quadrats in which it decreased had more than $50 \%$ cover of the species in 1987 . Four of the quadrats that 
remained the same had no $P$. annua cover in 1987. The change score for $P$. annua was significantly positively correlated with slope in $1987(\mathrm{r}=0.388, \mathrm{P}=0.015)$, bare ground in $1987(\mathrm{r}=0.369, \mathrm{P}=0.021)$, the change score for the third ordination axis mds $3(\mathrm{r}=0.685, \mathrm{P}$ $=0.000)$, the change score for seal disturbance $(\mathrm{r}=0.414, \mathrm{P}=0.009)$, and the change score for Callitriche antarctica $(\mathrm{r}=0.352, \mathrm{P}=0.028)$. It was significantly negatively associated with the change score for bare ground $(r=-0.432, P=0.006)$ and the change score for the first ordination axis mds $1(\mathrm{r}=-0.481, \mathrm{P}=0.003)$. These relationships indicate that the expansion of $P$. annua was associated with expansion and/or intensification of disturbance by seals, which also favoured expansion of Callitriche, an oft-noted characteriser of the vegetation of old seal wallows (Scott and Bergstrom, in press). P. annua expanded more where there was bare ground in 1987, a partial consequence of this expansion being a decrease in bare ground between 1987 and 2000.

The many significant changes in abundance recorded for other taxa do not appear to be the result of the expansion of $P$. annua, given that the only change score that was significantly correlated with the $P$. annua change score seems to be clearly explained by the increased seal activity, which was also associated with $P$. annua expansion. It seems highly likely that the decrease in abundance of Pringlea, Deschampsia and Ceratodon relates to trampling by moulting elephant seals and that the increase in filamentous green algae relates to an increased number of damp, fertile hollows created by their wallowing. The expansion of Azorella selago is most logically related to ongoing colonization of glacial moraines in an environment of climatic amelioration, likewise the expansion of $P$. cookii, although the latter is also favoured by the ongoing addition of nutrients from molting seals (Scott and Bergstrom, in press). The change scores for a large proportion of the taxa were significantly positively correlated with the change score for species richness and the change score for the second ordination axis mds 2 (Table 4), whereas the change scores for $P$. annua were significantly correlated with change scores for $\mathrm{mds} 1$ and $\mathrm{mds} 3$, indicating independence of the change in $P$. annua from general changes in species richness.

\section{Discussion}

Between 1987 and 2000, the areal extent, density and abundance of $P$. annua in the original two populations at Winston and Stephenson Lagoons increased markedly (Fig. 2). At the Winston site in 1987, the transects had reached to the outer extent of the $P$. annua population, an area of about $100 \times 70 \mathrm{~m}$. The greatest concentration of plants in 1987 occurred in a moist area of $20 \times 30 \mathrm{~m}$ intensively used by molting elephant seals and centred around several springs and stream-lines in a shallow embayment adjacent to the lagoon. Only a scattering of plants occurred beyond this embayment. In 2000 , some areas of dense $P$. annua growth had expanded beyond the original outer extent of $100 \times 70 \mathrm{~m}$, and a scattering of plants extended for over $600 \mathrm{~m}$ north and northwest and over $380 \mathrm{~m}$ to the south (Fig. 2).

At Stephenson Lagoon in 1987, P. annua occurred within several similar sized areas which were also utilised by molting seals, but growth was less prolific (Scott, 1989). Overall vegetation cover was more sparse, indicative of well-drained moraines, and level of use by molting seals was lower than at the Winston site (H. Burton and J.J. Scott, unpublished data). $P$. annua occurred in several small discontinuous swards on dry gravelly seal-molt areas at the bases of low rocky moraines, and numerous scattered plants occurred along stream-lines connecting shallow lagoons amongst the moraines (Scott, 1989). See Figure 2. In 2000 the range and density of $P$. annua had increased overall in these habitats, although several of the 
smaller swards noted in 1987 had disappeared and been replaced by scattered Azorella cushions. P. annua had formed extensive swards, often with Deschampsia, on the sand/gravel flats adjacent to the central shallow lagoon, and was also found up to $450 \mathrm{~m}$ inland in small patches of mire vegetation on steep rocky moraines away from the influence of molting seals (Fig. 2).

The average rate of spread at the two sites between 1987 and 2000 was over $100 \mathrm{~m} \mathrm{y}$. This is similar to average rates of spread for several introduced plant species documented for Marion Island, although the rate of spread of $P$. annua on Marion was somewhat lower (Gremmen and Smith, 1999). Our data set provides no direct evidence that $P$. annua displaces other plant species in undisturbed vegetation. Rather, $P$. annua is favoured by the disturbances of seals (bare ground, manuring), along with some other taxa. Along with Callitriche antarctica and Montia fontana, $P$. annua was commonly observed invading damaged tussocks of $P$. cookii and Deschampsia once bare peat was exposed by seal trampling. However, in November 2000 , small $P$. annua plants were occasionally seen growing in undamaged Azorella cushions at the Winston site, and also growing on moraines inland of seal-influenced vegetation at both sites, either at the edges of apparently undisturbed mire vegetation or in moist mineral soils on sparsely vegetated moraines. To invalidate the hypothesis that $P$. annua will displace other plants on Heard Island would require frequent temporal data from photographic plots and some critical experimental work. The data analyzed here suggest strongly that the process of establishment and spread of $P$. annua is largely independent of ongoing processes of vegetation change on glacial moraines, apart from sites where vegetation development is influenced by seal disturbance.

Molting elephant seals appear to have had a major influence in the establishment and spread of $P$. annua at its two main sites on Heard Island. The apparent increase in levels of seal disturbance at the two sites as indicated by our data, especially at the Winston site, is unlikely to reflect an overall increase in elephant seal numbers on Heard Island. A population decline documented between 1949 and 1985 appears to have halted, with an intrinsic rate of increase of $0-0.9 \%$ per year since 1985 (Slip and Burton, 1999). It is more likely that the recorded increase in seal disturbance on the two sites relates to the development of vegetation which is adapted to a regime of seasonal disturbance and which in turn provides an increasingly attractive molting habitat.

It is apparent from our investigations that $P$. annua can also spread further afield into areas away from the influence of seals. An important factor here is climatic warming (see Thost and Allison, in press) and the new areas of ice-free land, along with the competition-free seedbed which these provide (Scott, 1990; Smith, 1986). On Marion Island, Gremmen (1997) has suggested that the increase in abundance of $P$. annua noted over the past two decades is related to temperature increases during this time, while on subantarctic lles Kerguelen (Frenot et al., 1997, 1998) and South Georgia (Smith, 2000) P. annua has been noted as an early colonizer of recently deglaciated environments. However, on Iles Kerguelen it is relatively transient in primary succession on newly deglaciated land due to a poor ability to access soil nutrients once nutrients leach downwards through the developing soil profile, while deeper-rooting species such as Poa kerguelensis are better long-term survivors in such environments (Frenot et al., 1998). P. annua usually requires ongoing biotic disturbance to provide bare ground through trampling, and nutrient enrichment through manuring and moulting, to become a locally dominant component in subantarctic vegetation. Its dominance in vegetation of biotically influenced sites such as seasonally-disturbed elephant seal wallows has been previously noted for lles Kerguelen and Iles Crozet (Frenot et 
al., 2001) and Marion Island (Gremmen, 1981, 1997), and for heavily-grazed and trampled reindeer areas on South Georgia (Walton and Smith, 1973; Smith, 2000). On Macquarie Island, $P$. annua thrives mainly on sites subject to disturbance such as seal wallows (Selkirk et al., 1990) and areas adjacent to penguin colonies. It also colonizes bare soil on new landslips and sites heavily grazed by rabbits, but it tends to be out-competed by native species within several years on these sites if disturbance is not continued (Scott, 1995; J.J. Scott and J.B. Kirkpatrick, unpublished data).

On Heard Island, the patterns of $P$. anmua establishment and expansion documented so far appear to fit the patterns described for other subantarctic islands. It can be predicted that $P$. annua will continue to spread around the island, colonizing coastal vegetation which is subjected to seasonal disturbance by seals and penguins both in recently deglaciated areas and areas of longer-established vegetation. Unknown factors in predicting its further expansion on Heard Island, especially into areas not affected by biotic disturbance, include the nutrient regimes of soils developing on recently deglaciated areas. This requires testing. For example, the extensive $P$. annua swards which have appeared at the Stephenson site since 1987 have mostly developed on relatively fine morainal outwash material along the edges of shallow lagoons and stream-lines, and may be benefiting from nutrient-rich deposits associated with changing levels in these water-bodies as well as from the presence of molting seals. No P. annua was found along a series of well-established and richly vegetated mires at the inland edge of moraines at the Winston site, suggesting that established vegetation communities which lack bare ground and which are not subject to biotic disturbance are not easily invaded by the species. This has certainly been observed at Marion Island (Gremmen, 1981), South Georgia (Walton and Smith, 1973) and Macquarie Island (Scott, 1995).

The rapid environmental changes which Heard Island is currently undergoing as a result of climatic warming and deglaciation makes introduction and establishment of further plant species likely, whether or not they are (a) aliens or indigenous species and (b) introduced by humans or dispersed naturally. Comprehensive quarantine measures applying to all visitors, and provisions for investigating and responding to new species recorded on the island, are a key part of the new management plan being prepared by the Australian Antarctic Division (E. McIvor, personal communication). These measures aim to ensure that Heard Island's status is maintained as a World Heritage subantarctic island still relatively undisturbed by humans.

\section{Acknowledgements}

Thanks to the Australian Antarctic Division for Scott's participation in the 1986-87, 1987-88 and 2000-01 Australian National Antarctic Research Expeditions to Heard Island. Thanks also to Ewan Mclvor, AAD, for helpful comments on an earlier version of the manuscript and for later discussions, Yves Frenot for useful discussions in the field, and the Australian Antarctic Data Centre for providing the data for Figure 1.

\section{References Cited}

Frenot, Y., Chown, S.L., Whinam., J., Selkirk, P.M., Convey, P., Skotnicki, M. and Bergstrom, D.M., 2005: Biological invasions in the Antarctic: extent, impacts and implications. Biological Reviews, 80: 45-72. 
"In press": Arctic, Antarctic and Alpine Research, June 2005

Frenot, Y., and Gloaguen, J.-C., 1994: Reproductive performance of native and alien phanerogams on a glacier foreland, lles Kerguelen. Polar Biology, 14: 473-481.

Frenot, Y., Gloaguen, J.-C., and Tréhen, P., 1997: Climate change in Kerguelen Islands and colonization of recently deglaciated areas by Poa kerguelensis and $P$. annua. In:

Battaglia, B., Valencia, J., and Walton, D.W.H. (eds.), Antarctic Communities: Species, Structure and Survival. Cambridge University Press, Cambridge, pp. 358-566.

Frenot, Y., Gloaguen, J.C., Cannavacciuolo, M. and Bellido, A. 1998: Primary succession on glacier forelands in the subantarctic Kerguelen Islands. J. Vegetation Science 9:75-84.

Frenot, Y., Gloaguen, J.-C., Massé, L. and Lebouvier, M., 2001: Human activities, ecosystem disturbance and plant invasions in subantarctic Crozet, Kerguelen and Amsterdam Islands. Biological Conservation, 101: 33-50.

Gremmen, N.J.M., 1981: The Vegetation of the Subantarctic Islands Marion and Prince Edward. The Hague: Junk Publishers. 145 pp.

Gremmen, N.J.M., 1997: Changes in the vegetation of sub-Antarctic Marion Island resulting from introduced vascular plants. In: Battaglia, B., Valencia, J., and Walton, D.W.H. (eds.), Antarctic Communities: Species, Structure and Survival. Cambridge University Press, Cambridge, pp. 417-423.

Gremmen, N.J.M., and Smith, V.R., 1999: New records of alien vascular plants from Marion and Prince Edward Islands, sub-Antarctic. Polar Biology, 21: 401-409.

Kiernan, K. and McConnell, A. 1999 Geomorphology of the sub-antarctic Australian Territory of Heard Island-McDonald Island. Australian Geographer 30:159-195.

Minchin, P., 1990: DECODA - Database for Ecological Community Data, Version 2.02. Australian National University, Canberra.

Ruddell, A., in press: An inventory of present glaciers on Heard Island and their historical variation. In Heard Island: Southern Ocean Sentinel. Ed. K. Green and E. Woehler. Surrey Beatty and Sons, Chipping Norton, Australia.

Scott, J. J., 1989: New records of vascular plants from Heard Island. Polar Record, 25: 37. 42.

Scott, J. J., 1990: Changes in vegetation on Heard Island 1947-1987. In: Kerry, K.R. \& Hempel, G. (eds.), Antarctic Ecosystems, Ecological Change and Conservation. Berlin, Springer Verlag, pp. 61-76.

Scott, J.J., 1995: Changes in vegetation on Macquarie Island coastal slopes, 1980-1990. PhD thesis, University of Tasmania, Hobart. $340 \mathrm{pp}$.

Scott, J.J., and Bergstrom, D.M., in press: Vegetation of Heard and McDonald Islands. In: Heard Island: Southern Ocean Sentinel. Ed. K. Green and E. Woehler. Surrey Beatty and Sons, Chipping Norton, Australia. 
"In press": Arctic, Antarctic and Alpine Research, June 2005

Selkirk, P.M., Seppelt. R.D., and Selkirk, D.R., 1990: Subantarctic Macquarie Island: Environment and Biology. Cambridge University Press, Cambridge. 285 pp.

Slip, D.J., and Burton, H.R., 1999: Population status and seasonal haulout patterns of the southern elephant seal (Mirounga leonina) at Heard Island. Antarctic Science, 11: 38-47.

Smith, J.M.B., 1986: Origins of Australasian tropicalpine and alpine floras. In: Barlow, B. (ed.), Flora and Fauna of Alpine Australasia. Ages and Origins. Commonwealth Scientific and Industrial Research Organisation, Melbourne, pp. 109-128.

Smith, R.I.L., 2000: Plant colonisation on a 45-year sequence of annual micromoraines on a South Georgia glacier foreland. In: Davison, W., Howard-Williams, C., and Broady, P., Antarctic Ecosystems: Models for Wider Ecological Understanding. Caxton Press, New Zealand, pp. 225-232.

Thost, D., and Allison, I., in press: The Climate of Heard Island. In: Heard Island: Southern Ocean Sentinel. Ed. K. Green and E. Woehler. Surrey Beatty and Sons, Chipping Norton, Australia.

Walton, D.W.H., and Smith, R.I.L., 1973: Status of the alien vascular flora of South Georgia. British Antarctic Survey Bull., 36: 79-97. 
"In press": Arctic, Antarctic and Alpine Research, June 2005

Table 1. Transition matrix of communities $1987-2000$. Cells show the number of quadrats that were classified into one group in 1987 and the same or another in 2000 (e.g. the top left hand cell records 5 quadrats that fell in community one in both 1987 and 2000)

\begin{tabular}{lllllc} 
Community & \multicolumn{5}{c}{ Community 2000} \\
1987 & 1 & 2 & 3 & 4 & Total \\
1 & 1 & & & & \\
2 & 5 & 0 & 0 & 0 & 5 \\
3 & 2 & 2 & 0 & 0 & 4 \\
4 & 4 & 2 & 6 & 0 & 12 \\
Total & 1 & 0 & 1 & 14 & 16 \\
& 12 & 4 & 7 & 14 & 37
\end{tabular}


Table 2. Mean value of attributes by community. Means for a community are statistically identical at $\mathrm{P}>0.05$ (t-test) to another community if the letter/s next to the first community also occur as a part or whole of the letters next to another community. The probability value in the last column is derived from one way ANOVA. Cover scores were used as input for bare ground, rock, water and plant species, and visual estimate classes were used for seal disturbance (see Methods), while 'mds' represents ordination axis scores.

\section{Variable}

Altitude (m)

Aspect (deg.)

Slope (deg.)

Soil depth (cm)

Bare ground

Rock cover

Water cover

Seal disturb.

Vegetation ht $(\mathrm{cm})$

mas 1

mds 2

mds 3

Richness

Poa annua

Azorella selago

Callitriche

Colobanthus

Deschampsia $0.5 \mathrm{a}$

Montia

Poa cookii

Poakerguelensis

Pringlea

Ceratodon
1

$3.1 \mathrm{a}$

$177 \mathrm{a}$

$4.3 \mathrm{a}$

$8.1 \mathrm{a}$

$3.8 \mathrm{a}$

$3.4 \mathrm{a}$

$1.8 \mathrm{a}$

$2.4 \mathrm{a}$

$11.5 \mathrm{a}$

$0.45 \mathrm{a}$

$1.11 \mathrm{a}$

$-0.10 \mathrm{a}$

$5.4 \mathrm{a}$

$3.3 \mathrm{a}$

$0.8 \mathrm{a}$

$1.4 \mathrm{a}$

$0.2 \mathrm{a}$

$1.0 \mathrm{a}$

$2.9 \mathrm{a}$

$0.1 \mathrm{a}$

$0.3 \mathrm{a}$

$0.6 \mathrm{a}$
2

$3.9 \mathrm{a}$

$135 \mathrm{a}$

$9.4 b$

$7.0 \mathrm{a}$

$3.2 \mathrm{a}$

$3.2 \mathrm{a}$

$2.5 \mathrm{a}$

$1.8 \mathrm{~b}$

$16.9 \mathrm{ab}$

$0.53 \mathrm{a}$

$0.72 b$

$0.24 \mathrm{~b}$

$11.0 \mathrm{~b}$

$3.2 \mathrm{ab}$

$1.6 \mathrm{abc} 2.8 \mathrm{~b}$

$3.0 \mathrm{~b}$

$1.1 \mathrm{~b}$

$2.2 b$

2.66

$3.2 \mathrm{a}$

$0.2 \mathrm{a}$

$2.2 b c$

$1.4 \mathrm{~b}$

$1.6 b$

\section{Community}

3

$3.5 \mathrm{a}$

$163 \mathrm{a}$

$9.5 \mathrm{~b}$

$7.0 \mathrm{a}$

$3.7 \mathrm{a}$

$3.9 \mathrm{a}$

$0.0 \mathrm{~b}$

$1.8 \mathrm{~b}$

$16.3 \mathrm{ab} 10.5 \mathrm{ac} 0.003$

$0.87 \mathrm{~b}$

$0.72 b$

$0.15 b$

$9.3 \mathrm{~b}$

$2.0 \mathrm{bc}$

$1.9 \mathrm{c}$

$0.4 \mathrm{c}$

$1.4 \mathrm{~b}$

$1.8 \mathrm{c}$

$2.5 \mathrm{a}$

$1.0 \mathrm{~b}$

$2.8 \mathrm{~b}$

$1.4 \mathrm{~b}$
4

$6.3 b$

$133 \mathrm{a}$

$5.7 \mathrm{a}$

$8.2 \mathrm{a}$

$3.7 a$

$4.8 \mathrm{~b}$

$0.5 b$

$1.8 \mathrm{~b}$

$0.26 \mathrm{c}$

$0.98 \mathrm{a}$

$-0.04 a$

$5.1 \mathrm{a}$

$1.7 \mathrm{c}$

0.001

$0.2 \mathrm{c}$

$1.6 \mathrm{~b}$

$0.2 a$

$0.1 \mathrm{~d}$

$0.5 b$

$1.5 b$

$1.9 \mathrm{c}$

$0.0 \mathrm{c}$
$\mathbf{P}$

0.000

0.278

0.000

0.871

0.352

0.000

0.000

0.004

0.000

0.000

0.001

0.000

0.003

0.000

0.000

0.000

0.000

0.000

0.000

0.000

0.000 
Table 3. Means for variables and taxa for 1987 and 2000 and the ratios between them. The probability level is from the paired t-test. Cover scores were used as input for bare ground, rock, water and plant species, and visual estimate classes were used for seal disturbance (see Methods), while 'mds' represents ordination axis scores.

\begin{tabular}{|c|c|c|c|c|c|c|c|}
\hline Variable & 1987 & & 2000 & 200 & $/ 1987$ & & $\mathbf{P}$ \\
\hline mds 3 & 0.16 & & -0.12 & & -0.75 & & 0.000 \\
\hline Pringlea antiscorbutica & 2.28 & & 1.20 & & 0.53 & & 0.000 \\
\hline Deschampsia antarctica & 1.03 & & 0.59 & & 0.57 & & 0.009 \\
\hline Bryum /Pohlia spp. & 0.31 & & 0.18 & & 0.58 & & 0.230 \\
\hline Ceratodon purpureus 0.77 & & \multicolumn{2}{|l|}{0.49} & 0.64 & & \multicolumn{2}{|c|}{0.020} \\
\hline Marchantia berteroana & 0.33 & & 0.21 & & 0.64 & & 0.257 \\
\hline Vegetation height $(\mathrm{cm})$ & 14.8 & & 10.3 & & 0.70 & & 0.000 \\
\hline mds 1 & 1.04 & & 0.81 & & 0.78 & & 0.000 \\
\hline Colobanthus & 1.28 & & 1.00 & & 0.78 & & 0.054 \\
\hline Poa kerguelensis & 1.00 & & 0.79 & & 0.79 & & 0.073 \\
\hline Bare ground cover & 3.97 & & 3.46 & & 0.87 & & 0.001 \\
\hline Montia fontana & 1.00 & & 0.95 & & 0.95 & & 0.570 \\
\hline Rock cover & 4.13 & & 4.00 & & 0.97 & & 0.442 \\
\hline mds 2 & 0.91 & & 0.89 & & 0.98 & & 0.617 \\
\hline Richness & 6.64 & & 6.64 & & 1.00 & & 1.000 \\
\hline Acaena magellanica 0.15 & & 0.18 & & 1.20 & & 0.786 & \\
\hline Poa cookii & 1.67 & & 2.00 & & 1.20 & & 0.026 \\
\hline Polytrichastrum alpinum & 0.08 & & 0.10 & & 1.25 & & 0.661 \\
\hline Seal disturbance & 1.72 & & 2.18 & & 1.27 & & 0.001 \\
\hline Water cover & 0.74 & & 1.13 & & 1.53 & & 0.030 \\
\hline Azorella selago & 1.31 & & 2.31 & & 1.76 & & 0.000 \\
\hline Poa annua & 1.46 & & 3.08 & & 2.11 & & 0.000 \\
\hline Callitriche antarctica 0.51 & & 1.13 & & 2.22 & & 0.000 & \\
\hline Ditrichum sp. & 0.05 & & 0.18 & & 3.60 & & \\
\hline Filamentous green algae & 0.08 & & 0.41 & & 5.12 & & 0.014 \\
\hline
\end{tabular}


"In press": Arctic, Antarctic and Alpine Research, June 2005

Table 4. Correlations between change scores for taxa and those for the scores of the ordination axes and species richness. $*=\mathrm{P}<0.05, * *=\mathrm{P}<0.01, * * *=\mathrm{P}<0.001$.

\begin{tabular}{|c|c|c|c|c|}
\hline Taxon & Richness & MDS1 & MDS2 & MDS3 \\
\hline Poa annua & 0.234 & $-0.481 * *$ & 0.089 & $-0.628 * * *$ \\
\hline Callitriche antarctica -0.183 & -0.247 & 0.117 & -0.246 & \\
\hline Azorella selago & $0.502 * *$ & $0.421 *$ & $-0.773 * * *$ & 0.246 \\
\hline Colobanthus kerguel. $0.587 *$ & 0.133 & $-0.341 *$ & 0.095 & \\
\hline Deschampsia antarctica & $0.587 * * *$ & -0.084 & -0.263 & 0.248 \\
\hline Montia fontana & $0.434 * *$ & -0.010 & -0.142 & 0.048 \\
\hline Poa cookii & $0.450^{* *}$ & -0.138 & -0.111 & 0.055 \\
\hline Poakerguelensis & 0.207 & 0.323 & $-0.462 * *$ & 0.014 \\
\hline Pringlea antiscorbutica & $0.483 * *$ & -0.081 & -0.220 & -0.053 \\
\hline Ceratodon purpureus $0.497 *$ & $* \quad 0.073$ & $-0.545 *$ & 0.128 & \\
\hline Marchantia berteroana & $0.582 * * *$ & 0.126 & $-0.358 *$ & 0.274 \\
\hline Bryum /Pohlia spp. & $0.561 * * *$ & -0.072 & $-0.387 *$ & 0.020 \\
\hline Ditrichum sp. & $0.402 *$ & 0.276 & $-0.348 *$ & 0.112 \\
\hline Polytrichastrum alpinum & $0.323 *$ & 0.033 & -0.217 & 0.106 \\
\hline Filamentous green algae & $0.413 * *$ & -0.118 & -0.054 & -0.067 \\
\hline
\end{tabular}


"In press": Arctic, Antarctic and Alpine Research, June 2005

\section{Figure Captions}

Fig. 1. Location of Heard Island and study sites. Locations of sites shown in Figure 2 are indicated by boxes on inset maps. Topographic data for Heard Island supplied by Australian Antaretic Data Centre.

Fig. 2. Winston Lagoon and Stephenson Lagoon sites: location of transects and changes in Poa annua distribution 1987-2000. 
"In press": Arctic, Antarctic and Alpine Research, June 2005

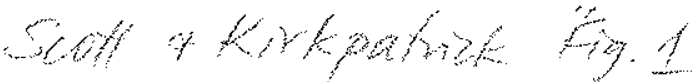

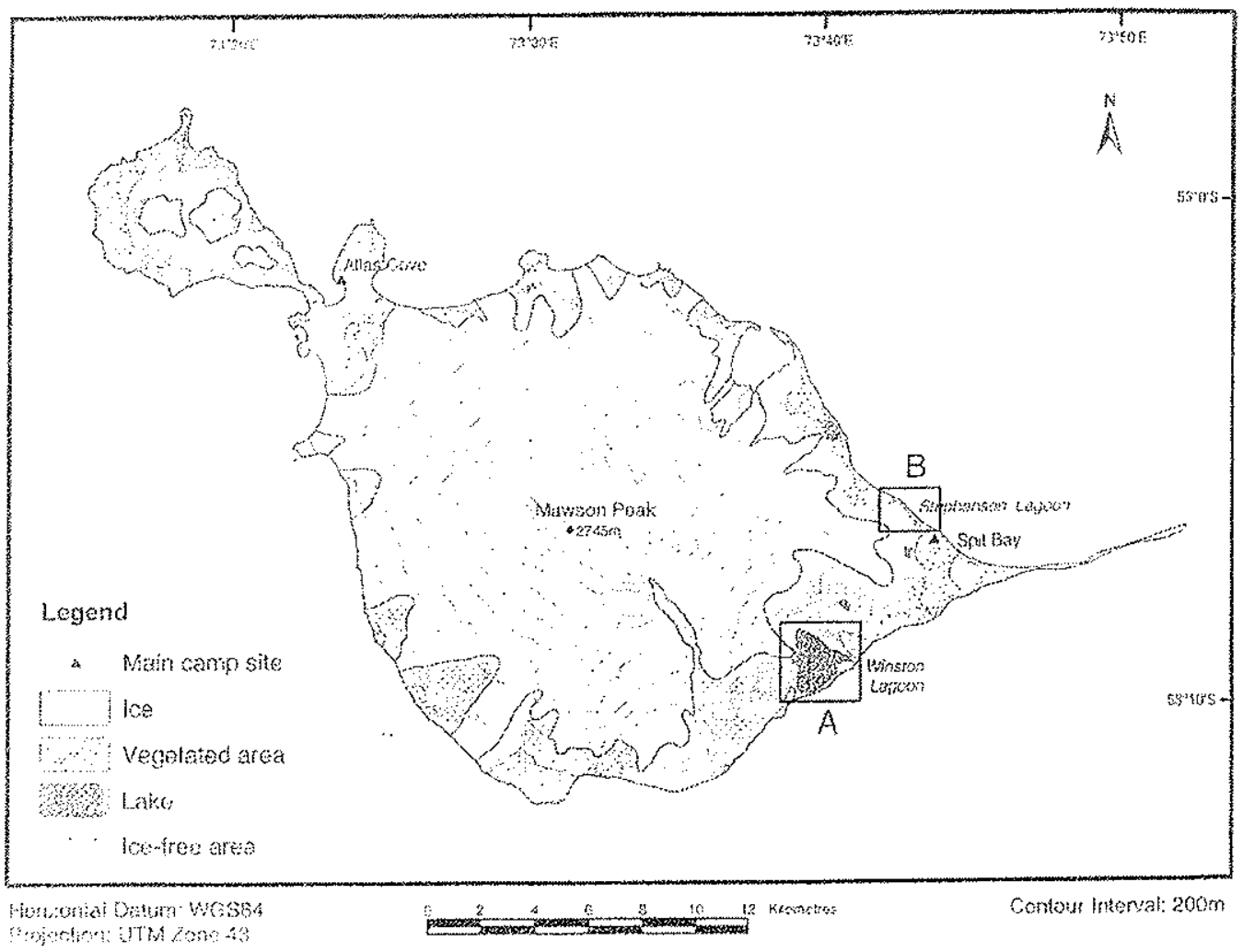

A Winston Lanoon

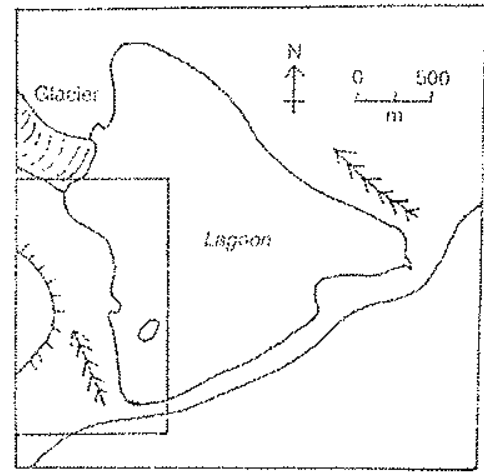

B Stemenson Lagoon

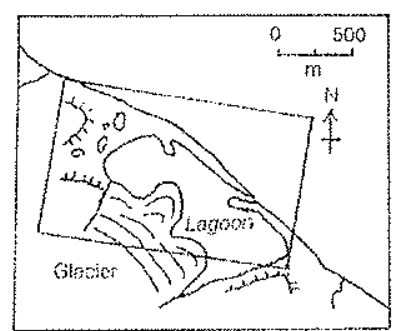


"In press": Arctic, Antarctic and Alpine Research, June 2005

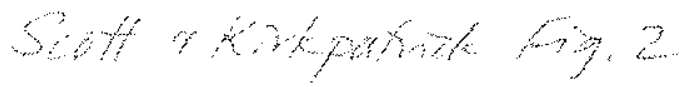
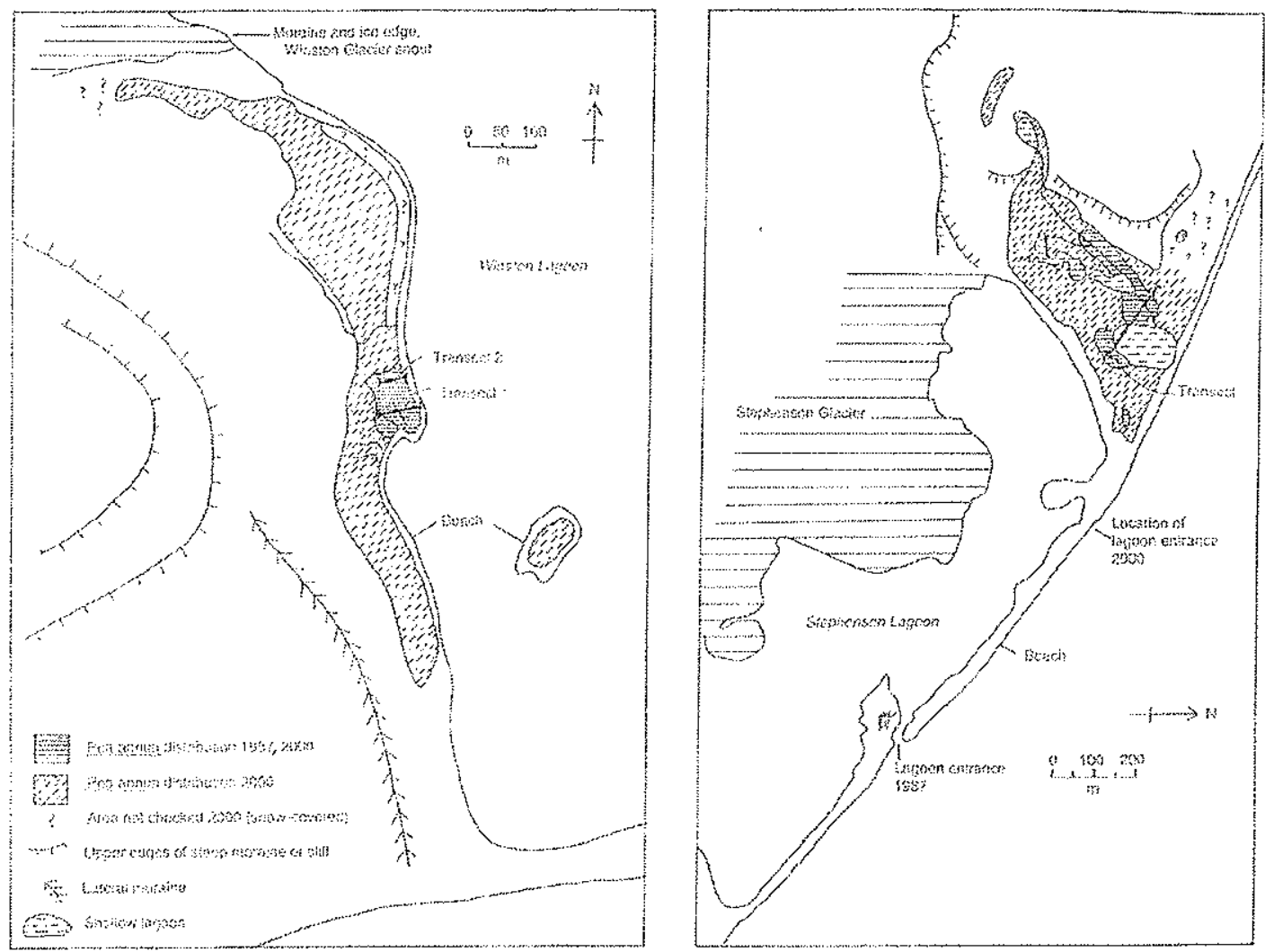